\title{
Renal Tubular Dysfunction in Male Inhabitants of a Cadmium-Polluted Area in Toyama, Japan - an Eleven-year Follow-up Study
}

\author{
Yunqing Cai, Keiko Aoshima, Terutaka Katoh, Hidetoyo Teranishi, and Minoru Kasuya
}

\begin{abstract}
An eleven-year follow-up study was carried out to elucidate the changes in the level of environmental exposure to cadmium (Cd) from rice after soil replacement of polluted paddy fields and these effects on urinary excretion of $\mathrm{Cd}$ in male inhabitants of a Cd-polluted area in Toyama, Japan. In addition, the prevalence of renal tubular dysfunction (RTD) was examined to clarify the progress of $\mathrm{Cd}$-induced RTD. One hundred and twenty-seven male inhabitants born between 1914 and 1929 in 11 districts of the Cd-polluted Jinzu River basin and 31 reference subjects in 2 adjacent districts were examined twice in 1985-86 and 1996-97. The geometric means of $\mathrm{Cd}$ concentrations in polished rice $(\mathrm{Cd}-\mathrm{R})$ in the Cd-polluted areas were $0.18 \mathrm{ppm}$ in 1985 and 0.21 $\mathrm{ppm}$ in 1986; these values were significantly higher than those of the reference areas $(0.13 \mathrm{ppm}$ in 1985 and $0.12 \mathrm{ppm}$ in 1986). After 11 years, the Cd-R levels were significantly decreased to approximately half $(0.08 \mathrm{ppm}$ in $1996,0.12 \mathrm{ppm}$ in 1997) due to soil replacement of polluted paddy fields, which has been carried out since 1980. The mean Cd levels in urine (Cd-U) were significantly reduced from 7.9 and $9.5 \mu \mathrm{g} / \mathrm{g}$ creatinine in the initial study to 6.9 and $6.8 \mu \mathrm{g} / \mathrm{g}$ creatinine in the follow-up study. However, the prevalence of RTD, which was determined by urinary $\mathrm{B}_{2}$-microglobulin exceeding $1 \mathrm{mg} / \mathrm{g}$ creatinine and urinary glucose exceeding $150 \mathrm{mg} / \mathrm{g}$ creatinine, increased from 18 and $23 \%$ in the $1985-86$ study to 25 and $32 \%$ in the $1996-97$ study, and a total of 12 new cases (12\%) of RTD were found. Whereas, only one subject $(4 \%)$ in the reference control areas was identified as RTD. Cd-induced RTD was prevalent, progressive and irreversible for male inhabitants of the Cd-polluted Jinzu River basin, although the environmental exposure to Cd through rice was significantly reduced by soil replacement of polluted paddy fields. J Epidemiol, $2001 ; 11: 180-189$
\end{abstract}

cadmium, renal tubular dysfunction, follow-up study, urinary $B_{2}$-microglobulin, Itai-itai disease

\section{INTRODUCTION}

Environmental pollution with cadmium $(\mathrm{Cd})$ and its effect on human health are important issues in Japan ". Itai-itai disease, which is characterized by osteomalacia in combination with proximal tubular dysfunction, was identified in the Jinzu River basin of Toyama Prefecture, Japan, and first reported by Kohno and Hagino in $1955^{2}$. Proximal tubular dysfunction, which is characterized by the increased urinary excretions of protein especially low-molecular weight proteins such as $\beta_{2}$ microglobulin, and glucose, amino acids and enzymes, was also identified in the inhabitants of the Itai-itai disease endemic area of the Jinzu River basin ${ }^{3-7}$. In this area, waste water con- taining $\mathrm{Cd}$ from an upstream mine had been discharged into the Jinzu River for about 50 years between the 1910's and 1950 's ${ }^{8)}$. These circumstances had resulted in Cd pollution of the soil in the rice fields by irrigation water ${ }^{9}$. The Prefectural Authorities carried out an extensive survey on Cd concentrations in rice and soil of the paddy fields in the Jinzu River basin over a 6-year period from $1971^{10}$, and they declared in 1977 that the upper soil layer of a total of $1,500.6$ ha of paddy fields should be replaced by non-polluted soil. An intervention program consisting of soil replacement of polluted paddy fields has been continually carried out since 1980 .

By implementing a series of countermeasures against soil pollution, it has been expected that a reduction in exposure to

Received February 2, 2001; accepted May 29, 2001

Address for correspondence : Keiko Aoshima, Department of Public Health, Faculty of Medicine, Toyama Medical and Pharmaceutical University, 2630 Sugitani, Toyama 930-0194, Japan. 
$\mathrm{Cd}$ through rice may induce somewhat favorable effects on health in the inhabitants of the Jinzu River basin. However, the findings of several follow-up studies showed that $\mathrm{Cd}$-induced renal tubular dysfunction is irreversible, even after reduction of exposure ${ }^{11-15)}$. Previous studies, however, mainly focused on female inhabitants and few studies on male inhabitants have been conducted concerning renal tubular dysfunction in a Cdpolluted area ${ }^{12,14}$. In addition, it was difficult to compare and interpret the results due to the lack of a control group. The present 11-year follow-up study for the first time aimed to compare the male inhabitants living in a Cd-polluted area with an adjacent reference area to elucidate the changes in the level of environmental exposure to $\mathrm{Cd}$ after soil replacement of polluted paddy fields and to clarify the prevalence and incidence of renal tubular dysfunction with urinary $\beta_{2}$-microglobulin and glucose as indices.

The soil replacement project was commenced in the upper districts of the polluted Jinzu River basin in 1980 and has been continually carried out, so the duration of rice cultivation in improved rice paddies in the target areas was different between the districts. In addition, in our previous study ${ }^{16}$ ), the prevalence of renal tubular dysfunction in the female population was noted to be different between the districts. Therefore, in the present study we attempted to grasp the local differences of exposure to $\mathrm{Cd}$ from rice and of the prevalence and incidence of renal tubular dysfunction in relation to the intervention program of soil replacement.

\section{SUBJECTS AND METHODS}

\section{Research areas}

Figure 1 shows the location of the research areas. Along the east-side and west-side areas of the Jinzu River basin, 11 districts, indicated by the letters B-L, including 24 hamlets, were selected. The paddy fields of these areas had been irrigated by Cd-polluted water discharged from an upstream mine through several irrigation ditches. Two districts, indicated by the letters $\mathrm{A}$ and $\mathrm{M}$, including 5 hamlets in the adjacent Ida and Kumano River basins were selected as references areas - these 2 districts being known as free from any man-made Cd contamination - for comparison with the Cd-polluted areas in the Jinzu River basin. As stated above, the soil replacement project of a total of 1,500.6 ha of paddy fields in the Jinzu River basin including the research area has been carried out since 1980 . The actual state of the soil replacement project of the research areas was previously described in detail ${ }^{16)}$.

\section{Subjects}

The initial study was conducted in the areas A-G in 1985 and in the areas H-M in 1986. The target population was all

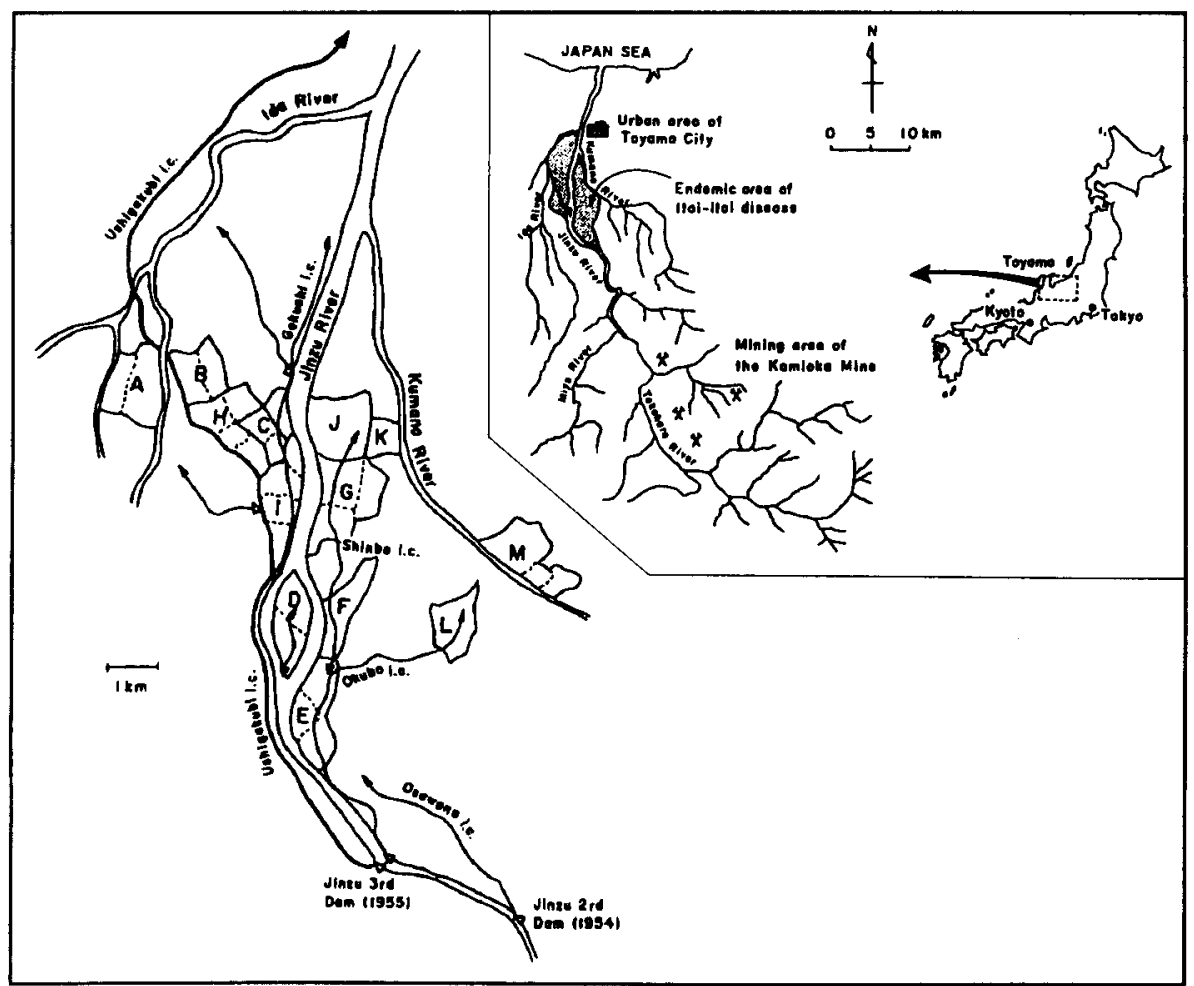

Figure 1. Map showing the location of the Jinzu River basin in Toyama Prefecture, Japan, and research areas. The letters B-L are cadmium-polluted districts, the letters $A$ and $M$ are reference districts. 
male inhabitants born between 1918 and 1927 (58-67 years old) in the areas A-G and between 1914 and 1929 (57-72 years old) in the areas H-M. A total of 317 eligible male inhabitants in the 13 districts (A-M) were identified from the municipal population register. Of these 317 males, 140 males $(89.7 \%)$ in the areas A-G and $145(90.0 \%)$ in the areas H-L participated (Table 1). After 11 years, the follow-up study was undertaken: 111 males $(79.3 \%)$ in the areas A-G and $103(71.3 \%)$ in the areas H-M were traced. A total of 71 subjects were not traced in the follow-up examination due to the following reasons; 55 (deceased), 6 (hospitalized), 2 (moved away), 7 (refused) and 1 (disease). Of the 55 deceased subjects, 47 inhabitants of the polluted districts (B-L) died from the following reasons; malignant neoplasm (17), cerebrovascular diseases (8), cardiovascular diseases (6), respiratory diseases (4), accidents (4), digestive diseases (3), and others (5). None of them died from renal disease. Five inhabitants of the polluted area were hospitalized with cerebrovascular diseases (3), lung cancer (1) and osteoarthritis of the knee (1). Two males from the polluted target area (B-L), who were designated as suspected Itai-itai disease patients by the government of Toyama Prefecture, participated in both the initial and the follow-up studies.

To evaluate the selective loss in the subjects in the follow-up study, a comparison of urinary $\boldsymbol{B}_{2}$-microglobulin or urinary glucose obtained from the initial study was made between the subjects followed-up and those lost to follow-up in each of the four areas of A, B-G, H-L and M. No significant differences in urinary $\beta_{2}$-microglobulin or urinary glucose were found between the follow-up and lost-follow-up groups, except in reference area $\mathrm{A}$, where the mean glucose concentrations in subjects lost to follow-up was significantly higher than that of the follow-up group $(413 \mathrm{mg} / \mathrm{g}$ creatinine vs. $56 \mathrm{mg} / \mathrm{g}$ creatinine).

Among the 214 males traced, 13 subjects including 2 in the reference district $M$ who had a history of residence in the $C d-$ polluted areas, 9 with diabetes mellitus and 2 with severe proteinuria not accompanied with glucosuria suggesting glomerulopathies were excluded. In addition, 43 with urinary $\mathrm{pH}<$ 5.50 were excluded because of degradation of $\beta_{2}$-microglobulin in acidic urine ${ }^{17,18)}$. Consequently, a total of 158 subjects ( 80 in the areas A-G and 78 in the areas H-M) were included in the analyses of the present study.

The characteristics of the subjects in each of the 13 districts (A-G and H-M) are summarized in Table 1. The average ages of the subjects in the 11 districts (B-L) were between 70.0 and 75.4 years old at the time of the follow-up. The average residence time for male inhabitants living in the Cd-polluted areas was 68 years at the time of the follow-up. Therefore, the inhabitants were exposed to excessive $\mathrm{Cd}$ for at least 50 years before soil replacement. Most subjects produced rice in their own rice

Table 1. Distribution and characteristics of male subjects in the reference areas (A, M) and in the cadmium-polluted areas (B-G, H-L) in Toyama, Japan, in an 11-year follow-up study, 1985-86 to 1996-97.

\begin{tabular}{|c|c|c|c|c|c|c|c|c|c|c|}
\hline $\begin{array}{l}\text { Sampling } \\
\text { sites }\end{array}$ & $\begin{array}{c}\text { Number of } \\
\text { participants } \\
\text { in initial } \\
\text { study }\end{array}$ & $\begin{array}{l}\text { Number of } \\
\text { subjects } \\
\text { followed-up } \\
(\%)\end{array}$ & $\begin{array}{l}\text { Number* } \\
\text { of } \\
\text { subjects } \\
\text { studied }\end{array}$ & $\begin{array}{l}\text { Age (years) } \\
\text { at follow-up } \\
\text { Mean } \pm \mathrm{SD}\end{array}$ & $\begin{array}{l}\text { Duration (years) of } \\
\text { residence in a } \\
\text { cadmium-polluted } \\
\text { area at follow-up } \\
\text { MeantSD }\end{array}$ & $\begin{array}{c}\text { Number of } \\
\text { persons } \\
\text { possessing } \\
\text { rice paddies (\%) }\end{array}$ & $\begin{array}{c}\text { Number of } \\
\text { persons } \\
\text { possessing } \\
\text { improved } \\
\text { rice paddies (\%) }\end{array}$ & $\begin{array}{l}\text { Duration (years) of } \\
\text { rice cultivation } \\
\text { in improved } \\
\text { rice paddies } \\
\text { M } \pm S D\end{array}$ & $\begin{array}{l}\text { Smoking status } \\
\text { in initial study } \\
\text { Current smokers / } \\
\text { Never smokers / } \\
\text { Former smokers }\end{array}$ & $\begin{array}{l}\text { Smoking status } \\
\text { at follow-up } \\
\text { Current smokers / } \\
\text { Never smokers / } \\
\text { Former smokers } \\
\end{array}$ \\
\hline \multicolumn{11}{|c|}{ Reference area } \\
\hline A & 35 & $29(82.9)$ & 20 & $72.6 \pm 3.2$ & 0 & $16(80.0)$ & $0(0)$ & 0 & $13 / 2 / 5$ & $7 / 2 / 11$ \\
\hline \multicolumn{11}{|c|}{ Cadmium-polluted area } \\
\hline $\mathrm{B}$ & 24 & $19(79.2)$ & 13 & $71.8 \pm 2.0$ & $64.6 \pm 17.3$ & $10(76.9)$ & $0(0)$ & 0 & $5 / 4 / 4$ & $3 / 4 / 6$ \\
\hline $\mathrm{C}$ & 28 & $19(67.9)$ & 15 & $72.1 \pm 3.0$ & $69.5 \pm 7.8$ & $11(73.3)$ & $10(90.9)$ & $1.8 \pm 1.2[10]$ & $8 / 1 / 5^{+}$ & $5 / 1 / 8^{+}$ \\
\hline $\mathrm{D}$ & 10 & $8(80.0)$ & 5 & $72.2 \pm 2.3$ & $67.6 \pm 11.1$ & $5(100.0)$ & $5(100.0)$ & $4.0 \pm 2.3[5]$ & $3 / 0 / 2$ & $2 / 0 / 3$ \\
\hline$E$ & 12 & $11(91.7)$ & 9 & $72.7 \pm 3.5$ & $68.3 \pm 8.9$ & $9(100.0)$ & $2(22.2)$ & $8.0 \pm 2.8[2]$ & $6 / 3 / 0$ & $4 / 3 / 2$ \\
\hline $\mathrm{F}$ & 12 & $8(66.7)$ & 4 & $70.0 \pm 2.0$ & $70.0 \pm 2.0$ & $4(100.0)$ & $2(50.0)$ & $10.5 \pm 7.8[2]$ & $3 / 1 / 0$ & $2 / 1 / 1$ \\
\hline $\mathbf{G}$ & 19 & $17(89.5)$ & 14 & $72.5 \pm 3.0$ & $70.6 \pm 3.6$ & $13(92.9)$ & $12(92.3)$ & $7.6 \pm 2.4[12]$ & $6 / 1 / 7$ & $4 / 1 / 9$ \\
\hline$B-G$ & 105 & $82(78.1)$ & 60 & $72.1 \pm 2.7$ & $68.4 \pm 10.1$ & $52(86.7)$ & $31(59.6)$ & $5.4 \pm 3.8[31]$ & $31 / 10 / 18$ & $20 / 10 / 29$ \\
\hline \multicolumn{11}{|c|}{ Reference area } \\
\hline $\mathbf{M}$ & 22 & $17(77.3)$ & 11 & $75.4 \pm 3.8$ & 0 & $11(100.0)$ & $0(0)$ & 0 & $4 / 6 / 1$ & $2 / 6 / 3$ \\
\hline \multicolumn{11}{|c|}{ Cadmium-polluted area } \\
\hline $\mathrm{H}$ & 16 & $11(68.8)$ & 8 & $72.4 \pm 2.9$ & $67.6 \pm 14.3$ & $6(75.0)$ & $6(100.0)$ & $2.8 \pm 1.2[6]$ & $6 / 0 / 2$ & $2 / 0 / 6$ \\
\hline I & 31 & $22(71.0)$ & 15 & $72.3 \pm 4.3$ & $67.4 \pm 10.8$ & $12(80.0)$ & $9(75.0)$ & $7.7 \pm 5.5[9]$ & $10 / 2 / 3$ & $7 / 2 / 6$ \\
\hline J & 26 & $18(69.2)$ & 16 & $74.6 \pm 5.2$ & $67.9 \pm 17.0$ & $14(87.5)$ & $6(42.9)$ & $5.3 \pm 2.1[6]$ & $9 / 4 / 3$ & $6 / 4 / 6$ \\
\hline $\mathrm{K}$ & 24 & $17(70.8)$ & 13 & $73.2 \pm 3.7$ & $68.5 \pm 10.0$ & $12(92.3)$ & $0(0)$ & 0 & $8 / 4 / 1$ & $7 / 3 / 3$ \\
\hline L & 26 & $18(69.2)$ & 15 & $75.0 \pm 5.4$ & $71.3 \pm 14.0$ & $13(86.7)$ & $1(7.7)$ & $16[1]$ & $9 / 5 / 1$ & $6 / 5 / 4$ \\
\hline $\mathrm{H}-\mathrm{L}$ & 123 & $86(69.9)$ & 67 & $73.6 \pm 4.6$ & $68.6 \pm 13.2$ & $57(85.1)$ & $22(38.6)$ & $6.1 \pm 4.6[22]$ & $42 / 15 / 10$ & $28 / 14 / 25$ \\
\hline
\end{tabular}

* Only persons with a urinary pH above 5.50 in both $1985-86$ and $1996-97$ were studied.

+ Data not available for same one person in district $C$. 
paddy fields. The rates of soil improvement of the polluted paddy fields in districts C, D, G, H and I were high (75-100\%) and in districts $\mathrm{E}, \mathrm{F}$ and $\mathrm{J}$ were low (20-50\%). However, in districts $\mathrm{B}, \mathrm{K}$ and $\mathrm{L}$ the soil replacement had not been commenced by the time of the follow-up study in 1996-1997. With regard to smoking habit, the subjects were classified into current smokers, never smokers and former smokers if they had stopped smoking by the time of the initial study or the followup study. The rates of current smokers were lower in the follow-up study than in the initial study. A total of 34 subjects stopped smoking during the follow-up.

\section{Sampling and analysis}

In both the initial and the follow-up studies, each subject was asked a self-administered questionnaire to obtain information about the history of residence and profession, possession and improvement of rice paddies, health status, cigarette smoking habit and use of medication. A rice sample from that consumed daily by the subject was collected. The information about the type of rice (i.e. whether the rice was produced in his-own rice field or purchased) was also obtained. Moming urine specimens were collected in polypropylene containers that were previously washed with nitric acid (1:4). Immediately after collection, the urinary $\mathrm{pH}$ was measured with a digital $\mathrm{pH}$ meter using a glass electrode. The urine samples were transferred to several tubes; the samples for $B_{2}$-microglobulin measurement were kept above $\mathrm{pH} 6.0$ by adding an ammonia solution $(0.25 \% \mathrm{v} / \mathrm{v})$, and for $\mathrm{Cd}$ determination they were kept acidified by adding nitric acid $(1 \% \mathrm{v} / \mathrm{v})$. All urine samples were stored at $-20^{\circ} \mathrm{C}$ until the analysis was performed. A radio-immunoassay method was used to measure the urinary $\boldsymbol{B}_{2}$-microglobulin ( $\beta_{2}$-Microglobulin Radioimmunoassay Kit, Eiken Chemical Co., Ltd., Tokyo). Urinary glucose was determined by an enzymatic method (Glucose C-test Wako, Wako Pure Chemical Ind., Osaka). Creatinine analysis was performed by Jaffe's method (Creatinine-test Wako). These measurements had been done within one month after urine collection. The same person performed the measurement of $\beta_{2}$-microglobulin in urine in both the initial and the follow-up studies. The quality control for the measurement of $\beta_{2}$-microglobulin was performed at the follow-up examination and involved analysis of reference serum samples with a known level of $\beta_{2}$-microglobulin for each analysis day. The mean of the intra-assay precision $(\mathrm{CV} \%)$ was $3.8 \pm 0.6 \%$ (mean $\pm \mathrm{SE}, \mathrm{N}=10$ ) in the 1996 study and $3.5 \pm 1.0 \%(\mathrm{~N}=11)$ in the 1997 study. The intra-assay precision was $7.2 \%$ at $1.48 \mathrm{mg} /$ liter $B_{2}$-microglobulin in serum in the 1996 study and $2.3 \%$ at $1.17 \mathrm{mg} /$ liter $\beta_{2}$-microglobulin in serum in the 1997 study. No strict quality control for the measurement of $\beta_{2}$-microglobulin was done in the 1985 and 1986 study. Therefore, reanalysis for $\beta_{2}$-microglobulin of the 17 urine samples from the 1986 study was performed in 1997 and there was a good correlation between the measurements in 1986 and $1997(r=0.99, Y(1986)=0.949 X(1997)-0.054)$.
For the measurement of urinary glucose, daily and yearly variations were checked routinely in our laboratory.

The Japan Food Research Laboratories (Tokyo) determined the measurement of $\mathrm{Cd}$ in rice. The concentrations of $\mathrm{Cd}$ in rice were measured using an atomic absorption spectrometer after wet ashing with $\mathrm{H}_{2} \mathrm{SO}_{4} / \mathrm{HNO}_{3}$, and extraction was achieved with ammonium pyrrolidine dithiocarbamate and acetic acid butyl keton. Urinary Cd was measured using an atomic absorption spectrometer with Zeeman background correction (Perkin Elmer Model No. 4100ZL) equipped with a graphite furnace and AS-70 autosampler. For the determination of $\mathrm{Cd}$ in urine, palladium nitrate was used as the matrix modifier ${ }^{19}$. Matrix matched calibration graphs were obtained from specimens prepared with addition of appropriate concentrations of $\mathrm{Cd}$ standard solutions in $0.5 \%$ nitric acid medium to urine samples with low $\mathrm{Cd}$ concentrations. For internal quality control, commercially available reference materials (Toxic Metals in Freeze-Dried Urine SRM2670 from the National Institute of Standard and Technology, USA) were used. The findings of the reference materials for each analysis day were within the certified values. The detection limit for $\mathrm{Cd}$ in urine was $0.26 \mu \mathrm{g} / \mathrm{liter}$. The determinations of $\mathrm{Cd}$ in urine and in rice obtained from the initial and the follow-up studies were performed between 1998 and 1999.

\section{Statistical analysis}

The values of urinary $B_{2}$-microglobulin, glucose and $\mathrm{Cd}$ were all adjusted for creatinine concentration. The samples with urinary creatinine concentrations $\geqq 0.25$ g/liter and $\leqq 3$ g/liter were accepted for the analysis in the present study, and all the 158 samples were accepted. For those quantities with skewed distributions, logarithmic transformations were carried out and expressed as the geometric mean (GM) and geometricstandard deviation (GSD). In view of the small numbers, the Mann-Whitney $U$ test was used to test the statistical significance for the values between the Cd-polluted areas and the reference areas. Wilcoxon signed-ranks test for paired data was used for testing the significance of the values between the initial examination and the follow-up examination. Fisher's exact probability test was used for testing the significance of prevalence and incidence of renal tubular dysfunction between the $\mathrm{Cd}$-polluted areas and the reference areas. The level of significance was set at $\mathrm{p}<0.05$. The statistical analysis was conducted using the StatView 5.0 software package.

\section{RESULTS}

Changes in cadmium levels in polished rice after soil replacement

Of 158 subjects studied, 145 (92\%) offered rice samples in both the initial study and the follow-up study. The numbers (rates) of rice samples produced by the subjects in the areas $\mathrm{A}$, B-G, M and H-L were 15 (88\%), 46 (82\%), 11 (100\%) and 48 
$(79 \%)$ in the $1985-86$ study, and $14(82 \%), 39(70 \%), 11$ $(100 \%)$ and $50(82 \%)$ in the $1996-97$ study, respectively. The numbers (rates) of subjects who consumed only rice produced by the subjects (the domestic rice) in both the initial and the follow-up studies were $14(82 \%)$ in district $\mathrm{A}, 38(68 \%)$ in districts B-G, $11(100 \%)$ in district $M$ and $46(75 \%)$ in districts HL. The remaining 36 subjects showed several variations in consuming rice between the initial and the follow-up studies, for example, from the domestic rice to the purchased rice ( 1 in district $A, 8$ in districts $B-G$ and 2 in districts $H-L$ ), from the purchased rice to the domestic rice ( 1 in districts $B-G$ and 4 in districts $H-L$ ), and only the purchased rice ( 2 in district $A, 9$ in districts B-G and 9 in districts $\mathrm{H}-\mathrm{L}$ ).

The averages and ranges of $\mathrm{Cd}$ concentrations in all of the 145 rice samples collected and only in rice samples harvested in the 13 districts (A-G) (the domestic rice) are separately shown in Table 2. Significant decreases in the concentrations of $\mathrm{Cd}$ in polished rice consumed daily by the participants were identified in districts $\mathrm{C}, \mathrm{D}, \mathrm{G}$ and $\mathrm{H}$ showing from $0.18-0.32$ to 0.03-0.09 ppm. In only the domestic rice samples significant decreases in the concentrations of $\mathrm{Cd}$ in districts $\mathrm{C}, \mathrm{D}, \mathrm{G}, \mathrm{H}$ and $\mathbf{J}$ of the $\mathbf{C d}$-polluted areas were also identified. It was interesting to note that in the follow-up study the average concentrations of $\mathrm{Cd}$ in domestic rice in districts $\mathrm{C}, \mathrm{D}$ and $\mathrm{G}$ were sig- nificantly lower than that in reference district A. However, the levels of the $\mathrm{Cd}$ concentrations in domestic rice in districts $\mathrm{K}$ and $\mathrm{L}$ were not significantly different between the initial and the follow-up studies and were still significantly higher than that in reference district $M$ in the follow-up study. As shown in Table 1, in districts C, D, G, H, I and J, the implementation of soil replacement was commenced between 1980 and 19961997. However, in districts B, K and $\mathrm{L}$ the implementation of soil replacement had not been commenced by 1996-1997. Therefore, these findings indicated that the replacement of the polluted soil in the paddy fields resulted in the substantial reduction of $\mathrm{Cd}$ intake through rice for the inhabitants of the Jinzu River basin.

\section{Changes in urinary excretion of cadmium over 11 years}

Table 3 shows the geometric means for urinary excretions of $\mathrm{Cd}$ in the initial and the follow-up studies in the 13 districts (AG, H-M). In the Cd-polluted areas B-G, significant decreases in urinary excretion of $\mathrm{Cd}$ were found in districts $\mathrm{C}$ and $\mathrm{G}$ with significant reductions in $\mathrm{Cd}$ in rice after 11 years, but not in district $\mathrm{D}$. In the Cd-polluted areas $\mathrm{H}-\mathrm{L}$, significant decreases in urinary $\mathrm{Cd}$ concentrations were found in districts $\mathrm{K}$ and $\mathrm{L}$ with no significant changes in $\mathrm{Cd}$ intake through rice. In reference district $M$, a significant decrease in urinary excretion of

Table 2. Cadmium levels in polished rice from male subjects in the reference areas $(A, M)$ and cadmium-polluted areas (B-G, H-L) in Toyama, Japan, in an 11-year follow-up study, 1985-86 to 1996-97.

\begin{tabular}{|c|c|c|c|c|c|c|}
\hline \multirow{2}{*}{ Site } & \multicolumn{2}{|c|}{ Cadmium in total polished rice (ppm) } & \multirow{2}{*}{$\mathrm{P}^{*}$} & \multicolumn{2}{|c|}{ Cadmium in domestic polished rice (ppm) } & \multirow{2}{*}{$\mathrm{P}^{+}$} \\
\hline & $1985-86$ & $1996-97$ & & $1985-86$ & $1996-97$ & \\
\hline \multicolumn{7}{|c|}{ Reference area } \\
\hline A & $0.13(0.05-0.28)[17]$ & $0.16(0.08-0.49)[17]$ & 0.120 & $0.13(0.05-0.28)[15]$ & $0.16(0.08-0.49)[14]$ & 0.183 \\
\hline \multicolumn{7}{|c|}{ Cadmium-polluted area } \\
\hline $\mathrm{B}$ & $0.20(0.06-0.58)^{\mathrm{a}}[13]$ & $0.16(0.05-0.88)[13]$ & 0.432 & $0.20(0.06-0.58)^{\mathrm{a}}[11]$ & $0.14(0.05-0.88)[7]$ & 0.222 \\
\hline $\mathrm{C}$ & $0.20(0.08-0.41)^{\mathrm{a}}[14]$ & $0.07(0.01-0.18)^{b}[14]$ & 0.001 & $0.27(0.12-0.41)^{\mathrm{a}}[7]$ & $0.07(0.01-0.18)^{\mathrm{a}}[\mathrm{T}]$ & 0.003 \\
\hline $\mathrm{D}$ & $0.32(0.21-0.43)^{b}[5]$ & $0.03(0.02-0.07)^{b}[5]$ & 0.043 & $0.32(0.21-0.43)^{b}[5]$ & $0.03(0.02-0.07)^{\mathrm{b}}[5]$ & 0.009 \\
\hline E & $0.08(0.02-0.42)[8]$ & $0.09(0.01-0.31)[8]$ & 0.932 & $0.08(0.02-0.42)[8]$ & $0.09(0.01-0.31)[8]$ & 0.834 \\
\hline F & $0.14(0.08-0.20)[3]$ & $0.10(0.05-0.38)[3]$ & 0.593 & $0.14(0.08-0.20)[3]$ & $0.10(0.05-0.38)[3]$ & 0.513 \\
\hline G & $0.18(0.04-0.63)[13]$ & $0.09(0.02-0.53)^{\mathrm{b}}[13]$ & 0.010 & $0.16(0.04-0.43)[12]$ & $0.07(0.02-0.13)^{\mathbf{b}}[9]$ & 0.043 \\
\hline$B-G$ & $0.18(0.02-0.63)^{\mathrm{a}}[56]$ & $0.09(0.01-0.88)^{\mathrm{b}}[56]$ & $<0.001$ & $0.18(0.02-0.58)^{\mathrm{a}}[46]$ & $0.08(0.01-0.88)^{\mathbf{b}}[39]$ & $<0.001$ \\
\hline \multicolumn{7}{|c|}{ Reference area } \\
\hline $\mathrm{M}$ & $0.12(0.06-0.22)[11]$ & $0.09(0.04-0.15)[11]$ & 0.109 & $0.12(0.06-0.22)[11]$ & $0.09(0.04-0.15)[11]$ & 0.094 \\
\hline \multicolumn{7}{|c|}{ Cadmium-polluted area } \\
\hline $\mathrm{H}$ & $0.21(0.10 \div 0.79)[7]$ & $0.03(0.01-0.12)^{\mathrm{a}}[7]$ & 0.018 & $0.27(0.10-0.79)[4]$ & $0.03(0.01-0.12)[5]$ & 0.027 \\
\hline I & $0.10(0.01-1.49)[14]$ & $0.04(0.01-0.27)[14]$ & 0.115 & $0.07(0.01-0.57)[10]$ & $0.03(0.01-0.27)[11]$ & 0.245 \\
\hline $\mathbf{J}$ & $0.30(0.09-0.86)^{\mathrm{b}}[13]$ & $0.13(0.01-0.77)[13]$ & 0.133 & $0.33(0.09-0.86)^{b}[11]$ & $0.13(0.01-0.77)[12]$ & 0.028 \\
\hline $\mathrm{K}$ & $0.29(0.10-1.14)^{\mathrm{b}}[12]$ & $0.29(0.02-0.74)^{b}[12]$ & $>0.999$ & $0.38(0.13-1.14)^{b}[9]$ & $0.43(0.23-0.74)^{b}[9]$ & 0.691 \\
\hline $\mathrm{L}$ & $0.25(0.02-2.12)[15]$ & $0.25(0.05-1.35)^{\mathrm{a}}[15]$ & $>0.999$ & $0.27(0.02-2.12)[14]$ & $0.25(0.05-1.35)^{\mathrm{a}}[13]$ & 0.846 \\
\hline$H-L$ & $0.21(0.01-2.12)^{\mathrm{a}}[61]$ & $0.11(0.01-1.35)[61]$ & 0.011 & $0.23(0.01-2.12)^{\mathrm{a}}[48]$ & $0.12(0.01-1.35)[50]$ & 0.024 \\
\hline
\end{tabular}

Values are geometric means with a range.

* Wilcoxon signed-ranks test for paired data between 1985 and 1996 (A to G) or 1986 and 1997 (H to M).

+ Mann-Whitney U test for data between 1985 and 1996 (A to G) or 1986 and 1997 (H to M).

${ }^{a} \mathrm{p}<0.05,{ }^{b} \quad \mathrm{p}<0.01$; Significant difference compared with the reference area ( $\mathrm{A}$ or $\mathrm{M}$ ) (Mann-Whitney $\mathrm{U}$ test).

[n] Number of rice samples examined. 
Table 3. Urinary levels of cadmium, $\beta_{2}$-microglobulin and glucose measured in the initial study (1985-86) and in the follow-up study (1996-97) in male subjects from the reference areas (A, M) and cadmium-polluted areas (B-G, H-L) in Toyama, Japan.

\begin{tabular}{|c|c|c|c|c|c|c|c|c|c|c|}
\hline \multirow{2}{*}{ Site } & \multirow{2}{*}{$\begin{array}{c}\text { Number of } \\
\text { Subjects }\end{array}$} & \multicolumn{2}{|c|}{ Cadmium ( $\mu \mathrm{g} / \mathrm{g}$ creat.) } & \multirow{2}{*}{$a^{+}$} & \multicolumn{2}{|c|}{ B2-microglobulin (mg/g creat.) } & \multirow{2}{*}{$\mathrm{P}^{+}$} & \multicolumn{2}{|c|}{ Glucose (mg/g creat.) } & \multirow{2}{*}{$\mathbf{P}^{+}$} \\
\hline & & $1985-86$ & $1996-97$ & & $1985-86$ & $1996-97$ & & 1985-86 & $1996-97$ & \\
\hline \multicolumn{11}{|c|}{ Reference area } \\
\hline A & 20 & $2.6(2.4)$ & $2.5(1.8)$ & 0.351 & $0.10(2.1)$ & $0.22(3.6)$ & 0.009 & $53(1.8)$ & $50(1.6)$ & 0.627 \\
\hline \multicolumn{11}{|c|}{ Cadmium-polluted area } \\
\hline B & 13 & $5.3(1.6)^{b}$ & $4.9(1.8)^{b}$ & 0.972 & $0.15(5.3)$ & $0.45(4.0)$ & 0.009 & $64(3.3)$ & $57(1.9)$ & 0.861 \\
\hline $\mathrm{C}$ & 15 & 11.7 & $9.4(1.8)^{b}$ & 0.041 & $4.59(5.1)^{\mathrm{b}}$ & $8.93(6.9)^{b}$ & 0.009 & $248(8.1)^{a}$ & 470 & 0.031 \\
\hline $\mathrm{D}$ & 5 & 9.7 & $8.6(1.4)^{b}$ & 0.893 & $0.32(2.9)^{\mathrm{a}}$ & $2.32(2.1)^{b}$ & 0.043 & $28(2.3)$ & & 0.043 \\
\hline $\mathrm{E}$ & 9 & 6.9( & $9.3(1.6)^{b}$ & 0.594 & $1.47(13.2)^{b}$ & $3.15(18.1)^{\mathrm{a}}$ & 0.015 & 120 & 204 & 0.051 \\
\hline $\mathrm{F}$ & 4 & 4. & 4.6 & 0.999 & $0.10(1.5)$ & $0.15(2.4)$ & 0.273 & 59 & $46(1.9)$ & 0.715 \\
\hline G & 14 & 9.0 & $5.9 i$ & $<0.005$ & $1.38(9.1)^{b}$ & $3.66(7.4)^{b}$ & 0.004 & $76(2.5)$ & $215(4.6)^{b}$ & 0.004 \\
\hline $\mathrm{B}-\mathrm{G}$ & 60 & 7 & $6.9(1$ & 006 & $0.86(9.7)^{b}$ & $2.22(9.3)^{b}$ & $<0.009$ & 3) & $159(5.6)^{\mathrm{b}}$ & $<0.001$ \\
\hline \multicolumn{11}{|c|}{ Reference area } \\
\hline $\mathbf{M}$ & 11 & $7.5(1.6)$ & $4.0(1.5)$ & 0.003 & $0.22(2.4)$ & $0.30(3.7)$ & 0.131 & $85(1.5)$ & $88(1.6)$ & 0.859 \\
\hline \multicolumn{11}{|c|}{ Cadmium-polluted area } \\
\hline $\mathrm{H}$ & 8 & $7.1(2.4)$ & 4.7 & 0.093 & $2.40(7.6)^{b}$ & $2.99(7.9)^{\mathrm{a}}$ & 0.161 & $193(4.2)$ & $347(5.8)$ & 0.208 \\
\hline I & 15 & 8.7( & $7.7(1.6)^{b}$ & 0.334 & $0.86(10.9)$ & $2.38(12.5)^{\mathrm{a}}$ & 0.003 & $138(4.4)$ & $287(5.9)$ & 0.027 \\
\hline J & 16 & $8.2(1$ & $7.1(1.5)^{b}$ & 1.163 & $2.76(7.6)^{b}$ & $4.70(8.4)^{b}$ & 0.070 & $119(5.8)$ & $131(5.3)$ & 0.438 \\
\hline K & 13 & $10.4(1.5)$ & $5.9(1.9)$ & 0.002 & $0.49(6.1)$ & $0.97(5.8)$ & 0.033 & $121(3.6)$ & $143(3.2)$ & 0.701 \\
\hline $\mathrm{L}$ & 15 & $13.1(1.6)^{\mathrm{a}}$ & $7.7(1.8)^{b}$ & $<0.001$ & $0.59(4.9)$ & $1.30(6.8)$ & 0.031 & $75(1.5)$ & $83(2.5)$ & 0.570 \\
\hline $\mathrm{H}-\mathrm{L}$ & 67 & $9.5(1.9)$ & $6.8(1.8)^{\mathrm{b}}$ & $<0.001$ & $1.06(7.8)^{b}$ & $2.11(8.4)^{b}$ & $<0.001$ & $118(3.8)$ & $161(4.6)$ & 0.016 \\
\hline
\end{tabular}

Values are geometric means with geometric standard deviations in parenthesis.

+ Wilcoxon signed-ranks test for paired data between 1985 and 1996 (A to G) or 1986 and 1997 (H to M).

${ }^{\mathrm{a}} \mathrm{p}<0.05,{ }^{\mathrm{b}} \mathrm{p}<0.01$; Significant difference compared with the reference area (A or M) (Mann-Whitney $\mathrm{U}$ test).

Table 4. Urinary levels of cadmium ( $\mu \mathrm{g} / \mathrm{g}$ creatinine) measured in the initial study (1985-86) and in the follow-up study (1996-97) in male subjects from the reference areas (A, M) and cadmium-polluted areas (B-G, H-L) in Toyama, Japan according to smoking habits.

\begin{tabular}{|c|c|c|c|c|c|c|c|c|c|c|c|c|}
\hline \multirow{2}{*}{ Site } & \multicolumn{4}{|c|}{ Current smokers } & \multicolumn{4}{|c|}{ Never or former } & \multicolumn{4}{|c|}{$\begin{array}{l}\text { Subjects who stopped smoking } \\
\text { during follow-up }\end{array}$} \\
\hline & $\mathrm{N}$ & $1985-86$ & 1996-97 & $\mathrm{P}^{+}$ & $\mathrm{N}$ & $1985-86$ & 1996-97 & $\mathrm{P}^{+}$ & $\mathrm{N}$ & $1985-86$ & $1996-97$ & $\mathrm{P}^{+}$ \\
\hline \multicolumn{13}{|c|}{ Reference area } \\
\hline A & 7 & $2.4(1.9)$ & $2.0(2.0)$ & 0.236 & 7 & $2.1(3.5)$ & $2.4(1.4)$ & 0.735 & 6 & $3.5(1.8)$ & $3.2(1.8)$ & 0.753 \\
\hline \multicolumn{13}{|c|}{ Cadmium-polluted area } \\
\hline B & 3 & $5.1(1.8)$ & $4.0(1.2)^{\mathrm{a}}$ & $>0.999$ & 8 & $4.9(1.6)$ & $4.5(1.9)^{\mathrm{a}}$ & 0.886 & 2 & $7.7(1.5)$ & $8.9(1.7)$ & 0.179 \\
\hline C & 5 & $9.2(1.3)^{b}$ & $8.4(1.6)^{b}$ & 0.345 & 6 & $11.4(1.6)^{b}$ & $7.0(1.3)^{b}$ & 0.046 & 3 & $16.4(1.3)^{\mathrm{a}}$ & $12.0(1.2)^{\mathrm{a}}$ & 0.108 \\
\hline D & 2 & $9.0(1.0)^{\mathrm{a}}$ & $9.7(1.5)^{\mathrm{a}}$ & 0.654 & 2 & $12.9(3.2)$ & $8.2(1.6)^{\mathrm{a}}$ & 0.654 & 1 & 6.2 & 7.7 & \\
\hline $\mathrm{E}$ & 4 & $10.0(2.0)^{\mathrm{b}}$ & $10.0(1.8)^{b}$ & 0.715 & 3 & $8.0(1.4)$ & $7.0(1.5)^{\mathrm{a}}$ & 0.285 & 2 & $12.5(1.7)$ & $12.1(1.2)^{\mathrm{a}}$ & 0.654 \\
\hline F & 2 & $3.0(1.4)$ & $3.5(3.7)$ & 0.654 & 1 & 6.4 & 6.5 & & 1 & 5.6 & 5.6 & \\
\hline G & 4 & $10.3(1.4)^{b}$ & $6.4(1.2)^{b}$ & 0.067 & 8 & $8.4(1.6)^{\mathrm{a}}$ & $5.2(1.6)^{\mathrm{a}}$ & 0.049 & 2 & $9.4(2.8)$ & $8.2(2.7)$ & 0.179 \\
\hline$B-G$ & 20 & $7.8(1.7)^{b}$ & $6.8(1.8)^{b}$ & 0.15 & 28 & $7.8(1.8)^{b}$ & $5.7(1.6)^{b}$ & 0.005 & 11 & $7.7(3.1)^{\mathrm{a}}$ & $9.5(1.6)^{6}$ & 0.656 \\
\hline \multicolumn{13}{|c|}{ Reference an } \\
\hline M & 2 & $10.8(1.3)$ & 5.2 & 0.1 & 7 & .4) & 2) & 0.018 & 2 & $3.8(1.6)$ & $2.7(1.2)$ & 0.179 \\
\hline \multicolumn{13}{|c|}{ Cadmium-polluted area } \\
\hline $\mathrm{H}$ & 2 & $4.6(1.9)$ & $5.5(3.7)$ & 0.654 & 2 & $6.6(1.7)$ & $3.7(1.7)$ & 0.179 & 4 & $9.1(3$ & $4.9(2.0)$ & 0.144 \\
\hline I & 7 & $5.4(1.9)$ & $6.2(1.5)$ & 0.499 & 5 & $14.8(1.4)^{b}$ & $9.7(1.4)^{b}$ & 0.079 & 3 & $11.3(2.5)$ & $8.7(1.7)$ & 0.285 \\
\hline $\mathrm{J}$ & 6 & $8.8(1.7)$ & $7.1(1.6)$ & 0.173 & 7 & $8.2(1.4)$ & $7.1(1.1)^{b}$ & 0.236 & 3 & $7.0(3.9)$ & $7.1(2.2)$ & $>0.999$ \\
\hline K & 6 & $9.1(1.6)$ & $6.4(1.9)$ & 0.027 & 4 & $13.6(1.3)^{\mathrm{a}}$ & $8.0(1.2)^{b}$ & 0.144 & 2 & $8.9(1.8)$ & $4.0(2.3)$ & 0.179 \\
\hline $\mathrm{L}$ & 6 & $17.0(1.4)$ & $11.0(1.6)$ & 0.046 & 6 & $12.4(1.7)$ & $6.8(1.8)$ & 0.027 & 3 & $8.7(1.5)$ & $4.9(1.3)$ & 0.108 \\
\hline $\mathrm{H}-\mathrm{L}$ & 27 & $8.6(1.9)$ & $7.2(1.8)$ & 0.064 & 24 & $10.8(1.6)$ & $7.3(1.5)^{b}$ & $<0.001$ & 15 & $8.9(2.3)$ & $5.8(1.8)$ & 0.010 \\
\hline
\end{tabular}

Values are geometric means with geometric standard deviation in parenthesis.

+ Wilcoxon signed-ranks test for paired data between 1985 and 1996 (A to G) or 1986 and 1997 (H to M).

${ }^{a} \mathrm{p}<0.05,{ }^{b} \mathrm{p}<0.01$; Significant difference compared with the reference area (A or M) (Mean-Whitney $U$ test). 
Cd was also found with no significant changes in $\mathrm{Cd}$ intake through rice. When subjects only consumed rice produced by the subjects in both the initial and the follow-up examinations were examined, similar results were obtained (data not shown).

Smoking is another major sources of exposure to Cd especially for males in Japan. Table 4 shows the geometric means for urinary excretion of $\mathrm{Cd}$ in the inhabitants of the 13 districts (A-G, H-M) according to their smoking habits at the initial and the follow-up examinations. In districts $C$ and $G$, significant decreases in urinary excretion of $\mathrm{Cd}$ were detected in the never or former smokers, but not detected in the current smokers or the subjects who stopped smoking during the follow-up. In the Cd-polluted areas H-L, significant decreases in urinary excretion of $\mathrm{Cd}$ were found in the never or former smokers in district $\mathrm{L}$. In addition, in districts $\mathrm{K}$ and $\mathrm{L}$ significant decreases in urinary excretion of $\mathrm{Cd}$ were identified in the current smokers. These findings indicated that urinary excretion of $\mathrm{Cd}$ might not reflect the changes in intake of $\mathrm{Cd}$ from rice in men in the present study.

Changes in urinary excretion of $\beta_{2}$-microglobulin and glucose over 11 years

The urinary excretions of $\beta_{2}$-microglobulin in the Cd-polluted areas B-G and H-L were significantly higher than in the ref- erence area $\mathrm{A}$ or $\mathrm{M}$ in both the initial and the follow-up studies (Table 3). After 11 years, significant increases were identified in districts $\mathrm{B}, \mathrm{C}, \mathrm{D}, \mathrm{E}$ and $\mathrm{G}$, and $\mathrm{I}, \mathrm{K}$ and $\mathrm{L}$. In reference district $A$, urinary excretion of $B_{2}$-microglobulin was also significantly increased from 0.10 to $0.22 \mathrm{mg} / \mathrm{g}$ creatinine. As shown in Table 1, although mean duration of rice cultivation in improved rice paddies in districts $\mathrm{G}$ and $\mathrm{I}$ was around 8 years, no favorable effect of reduction of Cd intake on urinary excretion of $B_{2}$-microglobulin was found. When subjects only consumed rice produced by the subjects in both the initial and the follow-up examinations were examined, similar results were obtained.

It was also noted that urinary excretions of $\beta_{2}$-microglobulin were highly correlated between the initial and the follow-up studies in the Cd-polluted areas: The Pearson correlation coefficient was 0.90 for the areas B-G, and 0.87 for the areas H-L. Age was slightly but significantly correlated with urinary excretions of $B_{2}$-microglobulin in both the initial and the follow-up studies: The Pearson correlation coefficients in the initial and the follow-up studies were 0.37 and 0.34 for the areas B-G, and 0.39 and 0.36 for the areas H-L, respectively.

The glucose concentrations in urine in the Cd-polluted areas B-G and H-L were significantly higher in the follow-up study than those in the initial study. No favorable effect of reduction

Table 5. Prevalence and incidence of $\beta_{2}$-microglobulinuria and renal tubular dysfunction (RTD) in the reference areas (A, M) and in the cadmium-polluted areas (B-G, H-L) in Toyama, Japan, in an 11-year follow-up study, 1985-86 to 1996-97.

\begin{tabular}{|c|c|c|c|c|c|c|c|}
\hline \multirow[b]{2}{*}{$\begin{array}{l}\text { Sampling } \\
\text { sites }\end{array}$} & \multirow{2}{*}{$\begin{array}{l}\text { Number of } \\
\text { subjects } \\
\text { examined }\end{array}$} & \multicolumn{2}{|c|}{ Prevalence of $\beta_{2}$-microglobulinuria } & \multirow{2}{*}{$\begin{array}{c}\text { Incidence of } \\
\text { Bz-microglobulinuria } \\
\%\end{array}$} & \multicolumn{2}{|c|}{ Prevalence of RTD } & \multirow{2}{*}{$\begin{array}{c}\text { Incidence of } \\
\text { RTD } \\
\%\end{array}$} \\
\hline & & $\begin{array}{l}1985-86 \\
\text { No. }(\%)\end{array}$ & $\begin{array}{l}1996-97 \\
\text { No. }(\%) \\
\end{array}$ & & $\begin{array}{l}1985-86 \\
\text { No. }(\%) \\
\end{array}$ & $\begin{array}{l}1996-97 \\
\text { No. }(\%) \\
\end{array}$ & \\
\hline \multicolumn{8}{|c|}{ Reference area } \\
\hline $\mathrm{A}$ & 20 & $0(0)$ & $1(5.0)$ & $5.0(1 / 20)$ & $0(0)$ & $0(0)$ & $0 \quad(0 / 20)$ \\
\hline \multicolumn{8}{|c|}{ Cadmium-polluted area } \\
\hline B & 13 & $2(15.4)$ & $5(38.5)^{*}$ & $27.3(3 / 11)$ & $0(0)$ & $0(0)$ & $0 \quad(0 / 13)$ \\
\hline $\mathrm{C}$ & 15 & $12(80.0)^{* *}$ & $13(86.7)^{* *}$ & $33.3(1 / 3)$ & $7(46.7)^{* *}$ & $10(66.7)^{* * *}$ & $37.5(3 / 8)^{*}$ \\
\hline $\mathrm{D}$ & 5 & $1(20.0)^{*}$ & $5(100)$ & $100.0(4 / 4)^{* *}$ & $0(0)$ & $1(20.0)^{*}$ & $25.0(1 / 5)^{*}$ \\
\hline $\mathrm{E}$ & 9 & $4(44.4)^{* *}$ & $5(55.6)^{* *}$ & $20.0(1 / 5)$ & $3(33.3)^{* *}$ & $3(33.3) * *$ & $0 \quad(0 / 6)$ \\
\hline $\mathrm{F}$ & 4 & $0(0)$ & $0(0)$ & $0.0(0 / 4)$ & $0(0)$ & $0(0)$ & $0 \quad(0 / 4)$ \\
\hline $\mathrm{G}$ & 14 & $7(50.0)^{* * *}$ & $10(71.4)^{* *}$ & $42.9(3 / 7)^{*}$ & $4(28.6)^{*}$ & $5(35.7)^{* *}$ & $10.0(1 / 10)$ \\
\hline$B-G$ & 60 & $26(43.3)^{* *}$ & $38(63.3)^{* *}$ & $35.3(12 / 34)^{*}$ & $14(23.3)^{*}$ & $19(31.7)^{* *}$ & $10.9(5 / 46)$ \\
\hline \multicolumn{8}{|c|}{$\frac{\mathrm{B}-\mathrm{U}}{\text { Reference area }}$} \\
\hline M & 11 & $1(9.1)$ & $2(18.2)$ & $10.0(1 / 10)$ & $0(0)$ & $1(9.1)$ & $9.1(1 / 11)$ \\
\hline \multicolumn{8}{|c|}{ Cadmium-polluted area } \\
\hline $\mathrm{H}$ & 8 & $5(62.5)^{*}$ & $5(62.5)$ & $33.3(1 / 3)$ & $2(25.0)$ & $3(37.5)$ & $16.7(1 / 6)$ \\
\hline I & 15 & $6(40.0)$ & $8(53.3)$ & $22.2(2 / 9)$ & $5(33.3)$ & $6(40.0)$ & $20.0(2 / 10)$ \\
\hline$J$ & 16 & $12(75.0)^{* *}$ & $13(81.3)^{* * *}$ & $50.0(2 / 4)$ & $4(25.0)$ & $4(25.0)$ & $8.3(1 / 12)$ \\
\hline K & 13 & $4(30.8)$ & $5(38.5)$ & $22.2(2 / 9)$ & $1(7.7)$ & $2(15.4)$ & $8.3(1 / 12)$ \\
\hline $\mathrm{L}$ & 15 & $6(40.0)$ & $8(53.3)$ & $33.3(3 / 9)$ & $0(0)$ & $2(13.3)$ & $13.3(2 / 15)$ \\
\hline$H-L$ & 67 & $33(49.3)^{*}$ & $39(58.2)^{*}$ & $29.4(10 / 35)$ & $12(17.9)$ & $17(25.4)$ & $12.7(7 / 55)$ \\
\hline
\end{tabular}

B2-Microglobulinuria was determined by urinary $\beta_{2}$-microglobulin exceeding $1 \mathrm{mg} / \mathrm{g}$ creatinine.

Renal tubular dysfunction (RTD) was determined by urinary B:-microglobulin exceeding $1 \mathrm{mg} / \mathrm{g}$ creatinine and urinary glucose exceeding $150 \mathrm{mg} / \mathrm{g}$ creatinine.

${ }^{*} \mathrm{p}<0.05,{ }^{* * *} \mathrm{p}<0.01$; Significant differences compared with the reference area (A or M) (Fisher's exact probability test). 
in exposure to $\mathrm{Cd}$ through rice on urinary excretion of glucose in districts $\mathrm{C}, \mathrm{D}, \mathrm{G}$ and $\mathrm{I}$ was found.

\section{Changes in the prevalence rates of $\beta_{2}$-microglobulinuria and renal tubular dysfunction over 11 years}

The prevalence of $B_{2}$-microglobulinuria determined by exceeding $1 \mathrm{mg} / \mathrm{g}$ creatinine in each of the 13 districts (A-M) is shown in Table 5 . The prevalence of $B_{2}$-microglobulinuria was extremely high in the Cd-polluted areas, and increased from $43.3 \%$ to $63.3 \%$ in areas B-G, and from $49.3 \%$ to $58.2 \%$ in areas $\mathrm{H}$-L after 11 years. The incidence rates of $\beta_{2}$-microglobulinuria in the Cd-polluted areas B-G (35.3\%) and H-L (29.4\%) were higher than those in the reference areas $\mathrm{A}(5.0 \%)$ and $\mathrm{M}$ $(10.0 \%)$, and significant differences were found in districts $D$ and $\mathrm{G}$ compared with in district $\mathrm{A}$.

The prevalence of renal tubular dysfunction determined by $\beta_{2}$-microglobulin exceeding $1 \mathrm{mg} / \mathrm{g}$ creatinine and glucose exceeding $150 \mathrm{mg} / \mathrm{g}$ creatinine is also shown in Table 5 . The prevalence of renal tubular dysfunction increased from $23.3 \%$ to $31.7 \%$ in the Cd-polluted areas B-G, and from $17.9 \%$ to $25.4 \%$ in the areas $\mathrm{H}-\mathrm{L}$ after 11 years. A total of 12 new cases of renal tubular dysfunction were found in the $\mathrm{Cd}$-polluted areas, and one in reference area M. No cases with renal tubular dysfunction were found to be recoverable based on the value of both the urinary $B_{2}$-microglobulin and glucose which dropped to below the cut-off value. Only two cases among 26 , found in the initial study, were excluded from the prevalence in the follow-up study because their urinary glucose levels decreased to below $150 \mathrm{mg} / \mathrm{g}$ creatinine, but their urinary $\beta_{2}$-microglobulin was still progressive. These findings demonstrated that the prognosis of Cd-induced renal tubular dysfunction for male subjects in the Jinzu River basin was deteriorated, and it was also possible to develop renal tubular dysfunction, even in Cdexposed subjects without renal tubular dysfunction in the initial study.

\section{DISCUSSION}

\section{Changes in exposure to cadmium from rice over 11 years}

The purpose of the present study was to assess the changes in the levels of exposure to $\mathrm{Cd}$ from rice after soil replacement of paddy fields for the male inhabitants in the Cd-polluted Jinzu River basin. In the target areas of the present study many professional farmers and farming families had produced only rice in their paddy fields and consumed their own produced rice throughout the year. Therefore, rice samples are suitable for exposure measurement to $\mathrm{Cd}$ in the subjects of the present study.

Previous studies, which determined $\mathrm{Cd}$ concentrations in rice in the Jinzu River basin, demonstrated that there was no indication that a substantial change in $\mathrm{Cd}$ exposure from rice had occurred between 1967 and $1977^{4,5,20)}$. In our previous study ${ }^{16)}$, the mean $\mathrm{Cd}$ concentration in domestic rice in the $\mathrm{Cd}$ - polluted areas B-G was $0.27 \mathrm{ppm}$ in 1983 and in areas $\mathrm{H}-\mathrm{L}$ was $0.33 \mathrm{ppm}$ in 1984 . These values were similar to the levels determined in 1967 in the same areas ${ }^{20}$. This suggests that $\mathrm{Cd}$ levels in rice had not changed between 1967 and 1984. In district I, the mean Cd level in rice in the initial study in 1986 was $0.07 \mathrm{ppm}$. In our previous study ${ }^{16}$, however, the mean $\mathrm{Cd}$ level in domestic rice collected from 12 female inhabitants in district I was $0.44 \mathrm{ppm}$ in 1984 . Consequently, a remarkable decline in $\mathrm{Cd}$ levels in rice collected from district I was found between 1984 and 1986, since district I was one of the earliest sites for the replacement of polluted soil. Therefore, the implementation of soil replacement in the paddy fields was clearly very effective to reduce $\mathrm{Cd}$ intake through rice for inhabitants in a Cd-polluted area.

Effects of changes in the levels of exposure to cadmium on urinary excretion of cadmium

In general, urinary excretion of $\mathrm{Cd}$ is considered to reflect the total body burden of $\mathrm{Cd}^{\mathrm{D}}$. Many studies have also suggested that urinary $\mathrm{Cd}$ is an indicator of $\mathrm{Cd}$ exposure and has a dose-response relationship with the levels of $\mathrm{Cd}$ in rice ${ }^{21,22)}$. Kido et al. ${ }^{22}$ investigated 1,815 inhabitants of the Cd-polluted Kakehashi River basin in Ishikawa Prefecture and 240 inhabitants of a reference control area; the inhabitants were divided into three groups according to the average $\mathrm{Cd}$ concentration in rice. In that study, the mean urinary $\mathrm{Cd}$ concentration was increased in a dose-related manner in inhabitants of the polluted area. In the present study, however, the examinations on a group basis of each 11 districts showed that significant decreases in urinary excretion of $\mathrm{Cd}$ were found in districts $\mathrm{C}$ and $\mathrm{G}$ with significant reductions in $\mathrm{Cd}$ in rice, and in districts $\mathrm{K}$ and $\mathrm{L}$ with no significant changes in $\mathrm{Cd}$ intake through rice. In reference district $\mathrm{M}$, a significant decrease in urinary excretion of $\mathrm{Cd}$ with no significant changes in $\mathrm{Cd}$ intake through rice was also found. These showed that urinary $\mathrm{Cd}$ excretion might not reflect the changes in exposure to $\mathrm{Cd}$ through rice in males in the present study.

In previous findings for female inhabitants, however, significant decreases in urinary excretion of $\mathrm{Cd}$ were found in accordance with the degrees of changes in $\mathrm{Cd}$ levels in rice ${ }^{16}$. One explanation for this discrepancy between males and females could be smoking, since smokers have been more exposed to $\mathrm{Cd}$ than non-smokers ${ }^{23,24)}$. Therefore, we examined the influences of smoking on the changes in urinary excretion of $\mathrm{Cd}$ for 11 years (Table 4). Significant decreases in urinary excretion of $\mathrm{Cd}$ were identified only in the never or former smokers in the Cd-polluted areas B-G and H-L. Thus, smoking habits influenced urinary excretion of $\mathrm{Cd}$ in males of the present study. However, in districts $\mathrm{K}$ and $\mathrm{L}$, significant decreases in urinary $\mathrm{Cd}$ were also identified in the current smokers. Although we could not fully explain these findings, several factors such as the reduction in rice intake and cigarette consumption with age might be considered ${ }^{23,25)}$. Consequently, it 
appears that the $\mathrm{Cd}$ level in urine is not a suitable monitoring indicator for $\mathrm{Cd}$ exposure from rice in inhabitants of a Cd-polluted area, especially in the males.

In reference district $\mathrm{M}$, urinary excretion of $\mathrm{Cd}$ was higher compared with that of district $\mathrm{A}$ in both the initial and the follow-up studies. A similar tendency was also found in women in our previous study ${ }^{16}$. The reasons why urinary excretions were higher in reference district $M$ could not be explained. However, one reason might be that the Kumano River originates from the range of mountains in which large-scale ore deposits rich in heavy metals including $\mathrm{Cd}$ exist and of which a representative is the Kamioka mine (Fig. 1). Cd concentrations in rice, however, were not different between district $M$ and district A (Table 2).

Changes in urinary excretion of $\beta_{2}$-microglobulin and glucose and prevalence rates of renal tubular dysfunction over 11 years

Few studies have focused on the prognosis of renal tubular dysfunction in males living in Cd-polluted areas in Japan. Since Itai-itai disease is prevalent in females, attention has been given more to females than to males ${ }^{4}$. Therefore, understanding the progress and prognosis of renal tubular dysfunction found in male inhabitants in $\mathrm{Cd}$-polluted areas has been limited.

A number of studies have demonstrated that urinary $\beta_{2}$ microglobulin excretion was a sensitive indicator to assess the changes in renal tubular function and was extensively used in epidemiological and occupational studies for $\mathrm{Cd}$-induced renal tubular dysfunction ${ }^{11-15,26,27}$. However, the use of an index for $B_{2}$-microglobulin in urine has not taken urinary $\mathrm{pH}$ into consideration in previous follow-up studies ${ }^{13-15,26)}$. Since $B_{2}-$ microglobulin is known to be unstable in urine with a $\mathrm{pH}<$ $5.50^{17}, 18$, even in the bladder, misleading results may be obtained for $\beta_{2}$-microglobulin evaluation without consideration of urinary $\mathrm{pH}$. Only those subjects whose urinary $\mathrm{pH}$ was above 5.50 were included in the analyses of the present study. Cd-induced renal tubular dysfunction is also accompanied by raised urinary glucose ${ }^{3,27,28)}$. Thus, in the present study, $\beta_{2}$ microglobulin and glucose were mainly used as indicators to assess the changes in renal tubular function.

As shown in Tables 3 and 5 , the urinary $B_{2}$-microglobulin concentrations of subjects living in the Cd-polluted areas B-G and $\mathrm{H}-\mathrm{L}$ were significantly increased after 11 years. Approximately $60 \%$ of male inhabitants had $\beta_{2}$-microglobulinuria determined by urinary $\beta_{2}$-microglobulin exceeding $1 \mathrm{mg} / \mathrm{g}$ creatinine at the time of the follow-up study. These findings clearly revealed that the male inhabitants studied had also been severely affected by exposure to Cd similar to females ${ }^{16)}$. Indeed, we previously reported that the male subjects with fractional excretion of $\boldsymbol{B}_{2}$-microglobulin ( $\mathrm{FE} \beta_{2}-\mathrm{m}$ ) exceeding $10 \%$, who were included in the present study, were at risk for development of osteomalacia, and those with FE $\beta_{2}-\mathrm{m}$ level exceeding 30\% manifested generalized proximal tubular dysfunction clinically as well as females ${ }^{27}$.

In the present study, clearly different prevalence rates of renal tubular dysfunction were found in the different areas within the Jinzu River basin in both the initial and the follow-up studies. As shown in Table 5, the prevalence rates of renal tubular dysfunction in districts $\mathrm{C}, \mathrm{E}, \mathrm{G}, \mathrm{H}, \mathrm{I}$ and $\mathrm{J}$ showed high rates ranging from $25 \%$ to $67 \%$. In contrast, the prevalence rates in districts $\mathrm{B}, \mathrm{D}, \mathrm{F}, \mathrm{K}$ and $\mathrm{L}$ showed lower levels ranging from $0 \%$ to $20 \%$. These differences could not be explained by the levels of $\mathrm{Cd}$ in rice produced in each district (Table 2), or by the intervention program of soil replacement (Table 1). These findings suggest that the local situations of each district, such as in relation to the irrigation ditches, are important determinants of changes in the prevalence and incidence of renal tubular dysfunction in the inhabitants of the Jinzu River basin ${ }^{6,16)}$.

$\mathrm{Cd}$ is accumulated in the kidney cortex with a biological half-time of 10-30 years ${ }^{12}$. Consequently, even if the exposure to $\mathrm{Cd}$ from rice were decreased, the concentration of $\mathrm{Cd}$ in the kidneys would not be decreased. Therefore, it is reasonable to suggest that it appears to be difficult to evaluate the effects of reduction of exposure to $\mathrm{Cd}$ from rice on renal tubular dysfunction in such cases with long-term exposure to $\mathrm{Cd}$. This suggests that a continuation of long-term follow-up studies, as reported here, is the most valuable means for elucidating the prognosis of renal tubular dysfunction among populations exposed to $\mathrm{Cd}$, and also the processes of the development in different genders.

One limitation of the present study was to reduce the subjects examined because of the acidic urine for evaluation of $B_{2}$ microglobulin. As previously reported ${ }^{18}$, mean urinary $\mathrm{pH}$ in males was more decreased than that in females. Almost 55\% of samples from males had a $\mathrm{pH}$ below 5.80. Therefore, a more stable index such as $\alpha$,-microglobulin or $\mathrm{N}$-acetyl- $\beta$-D-glucosaminidase should be used for further follow-up examinations.

\section{ACKNOWLEDGMENTS}

This study was supported by a Grant-in-Aid for Scientific Research (B) No. 09480121 from the Ministry of Education, Science, Sports and Culture, Japan. We thank Yumiko Kawanishi and Kiyo Watanabe for their help throughout this study.

\section{REFERENCES}

1. Friberg L, Piscator M, Nordberg GF, Kjellström T. Cadmium in the environment, 2nd ed. CRC Press Inc, Cleveland, 1974.

2. Kono M, Yoshida T, Sugihara H, et al. Report on socalled Itai-itai disease - First report. J Jpn Soc Orthop 1956; 30: 100-101. (in Japanese) 
3. Fukushima M, Ishizaki A, Nogawa K, et al. Epidemiological studies on renal failure of inhabitants in Itai-Itai disease endemic district. (Part I). Some urinary findings of inhabitants living in and around the endemic district of the Jinzu River basin. Jpn J Pub Health 1974; 21: 65-73. (in Japanese)

4. Kjellström T, Shiroishi K, Evrin PE. Urinary $B_{2-}$ microglobulin excretion among people exposed to cadmium in the general environment: an epidemiological study in cooperation between Japan and Sweden. Environ Res 1977; 13: 318-344.

5. Nogawa K, Ishizaki A. A comparison between cadmium in rice and renal effects among inhabitants of the Jinzu River basin. Environ Res 1979; 18: 410-420.

6. Aoshima K. Epidemiology of renal tubular dysfunction in the inhabitants of a cadmium-polluted area in the Jinzu River basin in Toyama Prefecture. Tohoku J Exp Med 1987; 152: 151-172.

7. Iwata K, Katoh T, Morikawa Y, Aoshima K, Nishijo M, Teranishi $\mathbf{H}$, Kasuya $M$. Urinary trehalase activity as an indicator of kidney injury due to environmental cadmium exposure. Arch Toxicol 1988; 62: 435-439.

8. Tonegawa $\mathrm{H}$. The technical management of Kamioka Mining \& Smelting and the history of mining pollution. In: Nogawa K, Kurachi M, Kasuya M, eds. Advances in the prevention of environmental cadmium pollution and countermeasures. Kanazawa, Japan, Eiko Laboratory, 1999: 174-177.

9. Fukushima M, Ishizaki A, Sakamoto M, et al. On distribution of heavy metals in rice field soil in the Itai-itai disease epidemic district. Jpn J Hyg 1970; 24: 64-73. (in Japanese)

10. Iwamoto A. Restoration of cadmium-polluted paddy fields in the Jinzu River basin - Progress and prospects of the restoration project - In: Nogawa K, Kurachi M, Kasuya M, eds. Advances in the prevention of environmental cadmium pollution and countermeasures. Kanazawa, Japan, Eiko Laboratory, 1999: 179-183.

11. Järup L, Persson B, Eling C, Elinder CG. Renal function impairment in workers previously exposed to cadmium. Nephron 1993; 64:75-81.

12. Iwata K, Saito H, Moriyama M, Nakano A. Renal tubular function after reduction of environmental cadmium exposure: a ten-year follow-up. Arch Environ Health 1993; 48: 157-163.

13. Roels H, Djubgang J, Buchet JP, et al. Evolution of cadmium-induced renal dysfunction in workers removed from exposure. Scand Work Environ Health 1982; 8: 191-200.

14. Kido T, Honda R, Tsuritani I, Yamaya H, Ishizaki M, Yamada $Y$, Nogawa $K$. Progress of renal dysfunction in inhabitants environmentally exposed to cadmium. Arch Environ Health 1988; 43: 213-217.
15. Roels HA, Lauwerys RR, Buchet JP, Bernard AM, Vos $A$, Oversteyns $M$. Health significance of cadmium induced renal dysfunction: a five year follow up. $\mathrm{Br} \mathrm{J}$ Ind Med 1989; 46: 755-764.

16. Fan J, Aoshima K, Katoh T, et al. A follow-up study on renal tubular dysfunction in women living in the cadmium-polluted Jinzu River basin in Toyama, Japan. Jpn J Hyg 1998; 53: 545-557. (in Japanese)

17. Evrin PE, Wibell L. The serum levels and urinary excretion of $B_{2}$-microglobulin in apparently healthy subjects. Scand J Clin Lab Invest 1972; 29: 69-74.

18. Aoshima $\mathrm{K}$, Kato $\mathrm{T}$, Teranishi $\mathrm{H}$, et al. The diagnostic value of urinary $\beta_{2}$-microglobulin, total protein, glucose and amino-acids for screening of cadmium nephropathy. Jpn J Pub Health 1990; 37: 881-887. (in Japanese)

19. Hosoda K, Omae K, Onodera M, et al. Comparison of matrix modifiers for simple determination of cadmium in blood and urine by graphite furnace atomic absorption spectrophotometry. Jpn J Ind Health 1994; 36: 102-103. (in Japanese)

20. Fukushima $M$, Ishizaki $A$, Sakamoto $M$, et al. Cadmium concentration in rice eaten by farmers in the Jinzu River basin. Jpn J Hyg 1973; 28: 406-415. (in Japanese)

21. Nogawa K, Ishizaki A, Kawano S. Statistical observations of the dose-response relationships of cadmium based on epidemiological studies in the Kakehashi River basin. Environ Res 1978; 15: 185-198.

22. Kido T, Nogawa K, Ohmichi M, Tsuritani I, Ishizaki M, Yamada Y. Significance of urinary cadmium concentration in a Japanese population environmentally exposed to cadmium. Arch Environ Health 1992; 47: 196-202.

23. Lewis GP, Jusko WJ, Coughlin LL. Cadmium accumulation in man: influence of smoking, occupation, alcoholic habit and disease. J Chron Dis 1972; 25: 717-726.

24. Hassler E, Lind B, Piscator M. Cadmium in blood and urine related to present and past exposure. A study of workers in an alkaline battery factory. $\mathrm{Br} \mathrm{J}$ Ind Med 1983; 40: 420-425.

25. Watanabe T, Shimbo S, Yasumoto Y, Imai Y, Kimura K, Yamamoto K, Kawamura S, Iwami O, Ikeda M. Reduction to one half in dietary intake of cadmium and lead among Japanese populations. Bull Environ Contam Toxicol 1994; 52: 196-202.

26. Stewart $M$, Hughes EG. Urinary $\beta_{2}$ microglobulin in the biological monitoring of cadmium workers. $\mathrm{Br} \mathrm{J}$ Ind Med 1981; 38: 170-174.

27. Aoshima K, Kawanishi Y, Fan J, Cai YQ, Katoh T, Teranishi H, Kasuya M. Cross-sectional assessment of renal function in the inhabitants of a cadmium-polluted area. Ann Clin Lab Sci 1995; 25: 493-503.

28. Saito H, Shioji R, Hurukawa Y, Nagai K, Arikawa T. Cadmium-induced proximal tubular dysfunction in a cadmium-polluted area. Contrib Nephrol 1977; 6: 1-12. 